\title{
Effects Of Asymmetric Information, Transaction Cost To Corporate Governance, And Public Organization Performance (Study In Local Water Company In Malang Regency)
}

\author{
Eddy Priyanto, Maryunani, GhozaliMazkie, M. Khusaini \\ Doctoral Postgraduate Program of Economics Science, Economics and Business Faculty, Brawijaya \\ University Malang 2013
}

\begin{abstract}
Governing government sector is not quite different with managing a company. When the purpose of private sector is to corporate stability and long-lasting profit ability, in fact the purpose of public sector is not much different. The purpose of public sector is to improve community welfare and community trust to government. Welfare itself could be accomplished if the implementation of the development program itself gives positive impact for the society. (Sifia from Aswanto, 2010)

When regional autonomy law is applied, Regional Government-owned Enterprise (BUMD) has potential which should be developed more through professional management by merging the characteristic of public service and profit orientation. Realizing good BUMD requires commitment from all parties from Regency/City Government as the owner and the manager of BUMD. From profit oriented aspect, BUMD (Malang Regency's PDAM) is one of the support and source of district own revenue (PAD), on the other hand PDAM is one of public organization which function is to provide clean water as one of public's commodity.

Corporate governance becomes an important issue in managing PDAM in Malang Regency since PDAM has a role as BUMD, which is given mandate to carry-out task from Malang Regency's Government in performing agency function, is feared to create many discrepancies in public business by asymmetric information which frequently occurs in the connection of some agencies which affects public organization performance in Malang Region PDAM.

Using Structural Equation Model (SEM), an analytical tool, using asymmetric information and transaction cost as independent variable, with corporate governance as intervening variable and public organization performance as dependent variable, the result of this research shows that transaction cost variable and asymmetric information has significant influence toward corporate governance, asymmetric information variable and transaction cost has indirect influence toward public organization performance through corporate governance variable, governance variable gives significant influence to public organization performance variable.
\end{abstract}

Keywords: corporate governance, assymetric information, transaction cost

\section{Introduction}

Managing government sector is similar to managing enterprise. If the main purpose of private sector is long-lasting viability of the company and everlasting profitability, in fact public sector is not much of different. The purpose of public sector is to improve the community welfare and community trust toward the government. Welfare could be achieved if the implementation of development program has positive impact to community. (Sifiaand Aswanto,2010).

When regional autonomyis applied, Regional Government-owned Enterprise (BUMD) has potential which should be developed more through professional management by merging public service and profitoriented aspect. realizing good BUMD requires commitment from all parties from Regency/City's Government as the owner and the manager of BUMD. Improving management requires improvement starts from planning, actuating, up to evaluation process so that its organizational performance could be improved.

In regional economy driver context, BUMD as regional economy stimulant are using two perspectives that are the strategic perspective as regional government-owned enterprise and the recent performance perspective (Noor, 2003). The first one is BUMD's strategic perspective as regional enterprise. Its existence and role of regional government-owned enterprise is becoming more strategic. It is mainly because of future socialpolitic consideration and BUMD's function as: (1) executor of government regulation in economy, (2) stimulus of community participation in economy. When BUMD's role as economy driver is neglected and economic activities are mostly dominated by large-scale non regional owned enterprise, it would be feared that government regulation implementations in economy sector in its region are marginalized. (Gana and Moenardy,2008).

In addition, BUMD has some roles which are expected to be able to stimulate district own source revenue (PAD). That role would be difficult to fulfill because State-Owned Enterprise (BUMN) and BUMD are managed in bureaucracy environment which is inefficient and lack of professionalism. Based on these problems, 
it is a very relevant discussion considering regional needs of financial sources which are able to stimulate district's own source of revenue is very crucial. (Alwi,2002)

The main BUMD's problem has the same characteristic as State-Owned Enterprise (BUMN). Legally, BUMN and BUMD have the same ways to organize resources and production activities. Namun, meski BUMD memiliki karakteristik yang sama, kinerja BUMD jauh ketinggalan dibanding BUMN. Salah satu penyebab, karena stakeholders terlihat kurang responsif dalam mengikuti dinamika yang ada khususnya dinamika pengelolaan,padahal jika dicermati banyak hal yang berlaku di BUMD dapat menjadi role model atau benchmark bagi pengelolaan BUMD. (Sunarsip,2009)

Corporate governance problem occurs as the impact of the parties involved inside the company who have different interests. Therefore it is quite interesting if that problem is grouped based on the characteristic of the company. The reason is that the main problem in corporate governance is different compared to the characteristic of the company.

We have to admit that inside regional government, there are relationship and agency problem particularly between business owner and manager of PDAM in Malang Regency in which there is principalagent problem which is caused by asymmetric information between principal and agent. In this problematic situation, agent has more information than principal which cause moral hazard (Belkaoui, 2000). Principal-agent problem discusses about the difficulties that occurs in condition of asymmetric information in which the action of one party affects other parties. According to Scoot (2003), he clearly stated that asymmetric information is on condition in business transaction in which one involved party has more information advantage than other parties.

The development of asymmetric information perspective is started form agency relation in which principal, as the owner of a company, gives authority to the agent so that potential of conflict of interest interests occur between both agent and principal (Lupia and BcCubbins, 2000). This conflict of interests occur because principal and agent has different interest. Asymmetric information could affect market efficiency in which one party tries to lessen information discrepancy by spending an amount of transaction cost (Pratt and Zeckhauser, 1985). Moreover, Milgrom and Roberts (1992) stated that transaction cost involves all loss caused by decisions, plans, regulations, or agreements which response inefficiently and agreement enforcement which is imperfect. In conclusion, transaction cost involves all costs which cause performance and ways to organize resources and production activities.

Essentially, transaction cost is paid by exchange parties in a non perfect information stated condition, which participated by opportunistic behaved actors, and providing bounded rationality. Transaction cost approach acknowledges imperfect transactional business exchange or asymmetry where transaction cost underlining concept such as, bounded rationality, opportunism, asset specificity, and asymmetric information.(Hobbs, 1997).Furubotndan Richter (as quoted by Benham and Benham, 200) show that transactional cost is an expense for using the market (market transaction costs) and expenses for receiving rights to give order in companies (managerial transaction costs) and expenses associated to mobilize and to adapt to institutional politics framework. (political transaction costs). Thus, high transaction costs will affect the increasing of product selling price so that it will burden consumers.

Sugiarto (2006) explains that the higher complexity of enterprise management activities the higher need of good corporate governance. Implementation of professional corporate governance is a vital matter according to the increasing competitiveness and globalization. Giving priority to improve and implement corporate governance, companies could lead to lower cost and performance improvement would increase customer and market trust.

Since good corporate governance is seen from occurrence of asymmetric information and level of transaction cost, it is interesting to see how the emergence process of asymmetric information with transactional cost and whether these who has correlation or not.

\section{Agency Theory}

\section{Literature Review}

Agency theory is one of theory, which arise within development of economics and modification of economic model; which adding behavioral aspects of human being. Agency theory is based on contract signed between shareholders or owners and management or manager. Based on this theory, the relationship between owner and manager are basically difficult to form because of conflict of interest between both parties. Conflicts of interest between principal and agent could create problems which under Agency Theory known as Asymmetric Information (AI) explained as unequal information caused by uneven information distribution between principal and agent. Dependency of external parties to accounting numbers, tendency of manager to maximize profit, and high level of AI cause the manager to manipulate performance reports for their own benefit. 
Concept of agency theory according to Anthony and Govindrajan (2001) is relationship or contract between principal and agent, where agency relationship took place when there is a contract between a person (or some people), one principal, and other person (or a few people), an agent to serve for principal's interest including delegation of authority and decision making to agent. Agent tries to maximize contractual fees which will be earned according to its required effort, while principal try to maximize returns from using resources depending on the fees paid to agent. (Belkaoui, 2001)

Principal-agent problem discusses about difficulties which will occur in condition of asymmetric information when principal hires the agent. Various mechanisms might be useful to harmonize agent's interest with principal's interest, such as fare or commission per unit, profit share, wage efficiency, performance measurement, etc. Principal-agent relationship happens if one's behavior affects others or when one party depends on other parties (Pratt and Zeckhauser, 1989 in Gilardi, 2001). Principal-agent problem occurs when principal delegate responsibilities to agents to carry out the responsibilities based on principal's interest. However, because of asymmetrical information owned by agent, it makes the agent not be able to complete the responsibilities without having required information.

Principal-agent problem occurs when the owner and the manager are not form the same side. Jensen and Mecling (1967), defines agency relationship as:

"a contract under which one or more persons (the principal/s) engage another person (the agent) to perform some service on their behalf which involves delegating some decisions making authority to the agent".

Principal-agent relationship is asymmetric information, where one party has more information than other party, so that creates ex-ante adverse selection from ex-post moral hazard. It means that the form of relationship between principal and agent continue going on with one sacrifice, called as agency cost or transaction cost, which affects institutional option. Moreover, Hoobs (1997) explains that institutional option also has close correlation with social economy condition such as education level, amount of family member, income, and business characteristic.

According to these definitions, agent is someone who makes economic decision for other people. In this situation, where there is separation between company ownership (principal) and management (in this case, manager act as agent) has potential to create principal-agent problem. Nicholson gives definition on agent as a party taking part as economic decision making (Nicholson, 1995). Ujiyanto, et al (2007) states that agent is at the position where they have more information about self capacity, working environment, and the company itself as a whole than principal.

\section{Transaction Cost Theory}

Classical/neoclassical economics assumes that transactions are free of cost. In other words, transaction could occur based on market mechanism without paying any costs. This view contradicts recent institutional economics thought which has opposite assumption. Market will not function perfectly if economic actor does not have information about goods which will be traded. Therefore, some economists are convinced that transaction can go on if the required information exists. Collecting information needs cost. Therefore, assumption stated that transaction could proceed without any cost becomes irrelevant. In that case, transaction costs become important analysis unit in institutional economics.

Transaction cost analysis enables looseness of perfect information assumption from neoclassical theory. Transaction cost approach acknowledges many businesses trading which are characterized as imperfect or asymmetric. Incompleteness information and uncertainty refer to a situation where all parties involved in transaction process are facing the same level of information which is vague. Asymmetric information occurs when availability of information for all parties and private information is only for specific parties, so that all parties do not have the same level of information. Asymmetric information could result in opportunistic behavior. Ex ante opportunism happens when information is hidden before transaction and this was first defined by Akerlof in 1970 about lemon market (Stigler, 1961).

Williamson (1995) introduced transaction cost of economics concept (TCE) or transaction cost economics and it is well known as transaction cost which is a synthesis from some disciplines; such as law, economics, and organizational science. Formulation of transaction cost was proposed by Ronald $\mathrm{H}$. at the first time. Coase in 1937 proposed it as new framework to analyze transaction in company. However, after that moment economist failed to operate this concept, until it was developed by Williamson, who cited his effort as "the new institutional economics which is the branch of transactional cost. TCE assumes that companies are tend to search for the cheapest transactional cost, that is comparing transaction cost from market (market transaction) with transaction cost within its own company (hierarchical transaction) or know as the term "make or buy". Emergence of TCE, according to Williamson, was due to market failure.

Williamson (1995) introduced transaction cost of economics concept (TCE) or transaction cost economics and it is well known as transaction cost which is a synthesis from some disciplines; such as law, 
economics, and organizational science. Formulation of transaction cost was proposed by Ronald $\mathrm{H}$. at the first time. Coase in 1937 proposed it as new framework to analyze transaction in company. However, after that moment economist failed to operate this concept, until it was developed by Williamson, who cited his effort as "the new institutional economics which is the branch of transactional cost. TCE assumes that companies are tend to search for the cheapest transactional cost, that is comparing transaction cost from market (market transaction) with transaction cost within its own company (hierarchical transaction) or know as the term "make or buy". Emergence of TCE, according to Williamson, was due to market failure.

Pass et al (2000) explains that transaction cost is occurred due to input, goods, service or asset exchange between two individuals or more and even between companies. Transaction could happen through market involve purchasing and selling using price system. Transaction could be internalized through various department and frequently use transfer pricing which is categorized as internal. Coase (1998) states that the lower transactional cost the higher specialization, the bigger economic productivity, and the higher living standard of the people within that economy. The level of transaction cost depends on certain institution within a country, political and law system, culture, etc.

Zhang (2000)has identified factors influencing transaction cost, as follows:

- Goods characteristic and the rights to those goods (according to information about goods and personal status on those things.

- Actor's identity is involved in transaction, related to bounded rationality of human's nature, that is limitation of human to search, accept, store, process information; lack of available information.

- Technical situation and social regulation, trading and things related to the trading.

Based on explanation about definition and factors influencing the amount of transaction cost Beckman (2009), formulated four determinant or transaction costs, which are:

1. Behavioral attributes of actors which are bounded rationality and opportunism.

2. Attributes of transaction which are asset specification uncertainty, and frequency.

3. Things related to government structures which are market, hierarchy, regulation, public bureaucracy.

4. Factors related to institutional environment includes ownership regulation, contract, and culture.

Figure 1. Influentian Factors on Transaction Cost

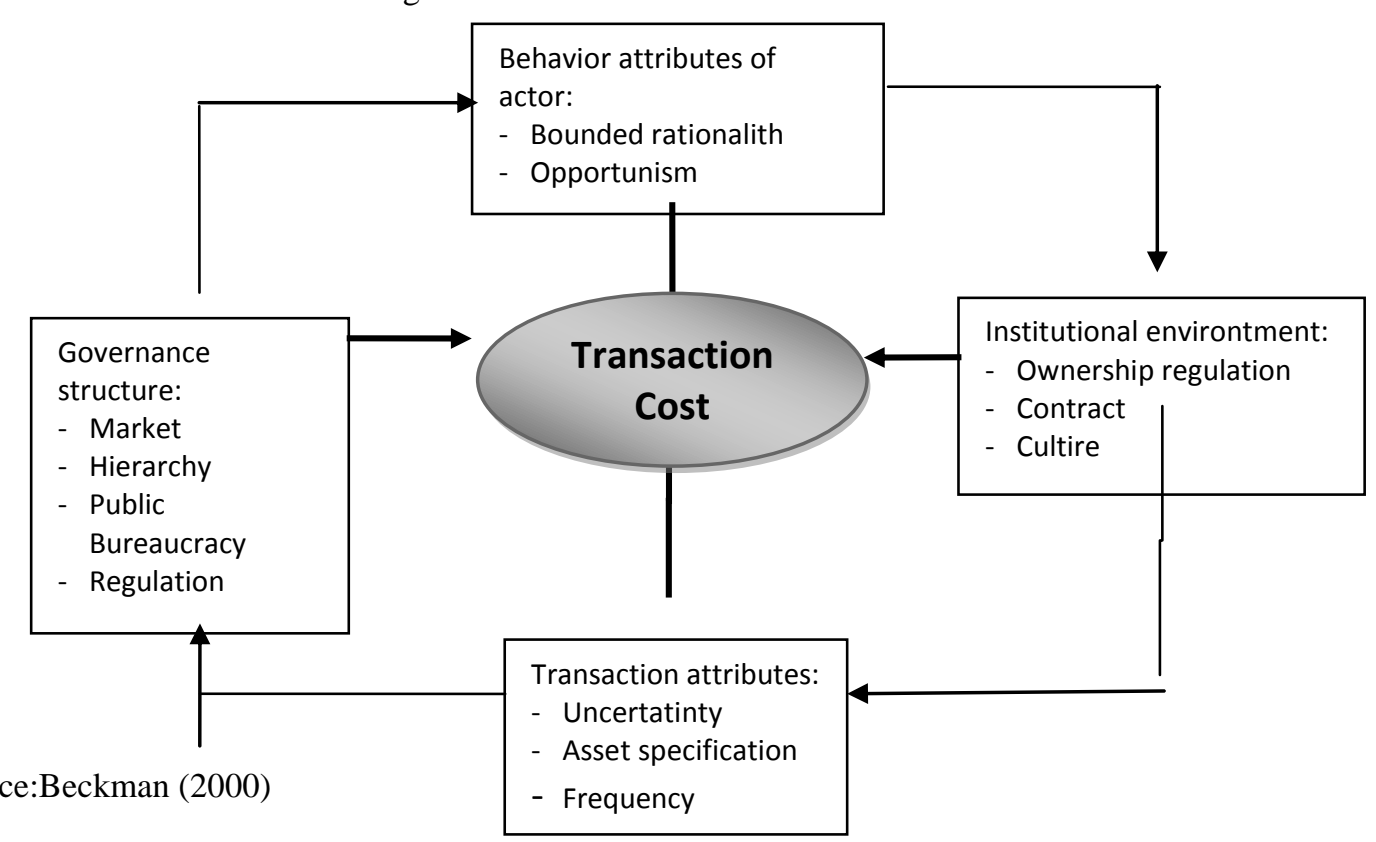

\section{Research Methodology}

This research is classified as quantitative research by using Structural Equation Model (SEM) analysis unit. This research uses 3 kinds of variables, those are dependent variable, independent variable, and also intervening variable. The dependent variable in this research is public organization performance (Y2) and the intervening variable is corporate governance (Y1). While the independent variable in this research consists of 2 variables, those are Asymmetric Information (X1) and transactional cost (X2). Thus, there are 4 variables in this research, which are 2 independent variables, 1 intervening variable and 1 dependent variable.

Structural equation of this research is as follows:

$\eta 1 \mathrm{KOP}=\gamma 1 \xi 1 \mathrm{IA}+\gamma 2 \xi 2 \mathrm{BT}+\gamma 3 \xi 3 \mathrm{CG}$ 
Description:

$\begin{array}{lll}\text { IA } & =\text { Asymmetric Information } \\ \text { BT } & =\text { Transaction Cost } \\ \text { CG } & =\text { Corporate Governance } \\ \text { KOP } & =\text { PublicOrganizationPerformance }\end{array}$

Variable Measurement Equation of Asymmetric Information $(\xi 1)$

$\begin{array}{ll}\xi 1=\lambda 1 \mathrm{X} 1+\varepsilon 1 & : \text { Information owned by subordinate compared with } \\ \text { superior } & : \text { Input-output relationship inside internal operation } \\ \xi 1=\lambda 2 \mathrm{X} 2+\varepsilon 2 & : \text { Potential performance } \\ \xi 1=\lambda 3 \mathrm{X} 3+\varepsilon 3 & : \text { Technical work } \\ \xi 1=\lambda 4 \mathrm{X} 4+\varepsilon 4 & : \text { Ability to assess potential impact } \\ \xi 1=\lambda 5 \mathrm{X} 5+\varepsilon 5 & : \text { Achievement in activity aspect } \\ \xi 1=\lambda 6 \mathrm{X} 6+\varepsilon 6 & \end{array}$

Measurement equation of transactional $\operatorname{cost}(\xi 2)$

$\begin{array}{ll}\xi 2=\lambda 7 \times 7+\varepsilon 7 & : \text { Behavior attribute of actor } \\ \xi 2=\lambda 8 \times 8+\varepsilon 8 & : \text { Transaction attribute } \\ \xi 2=\lambda 9 \times 9+\varepsilon 9 & \text { Governance structure } \\ \xi 2=\lambda 10 \times 10+\varepsilon 10 & : \text { institutional matter }\end{array}$

Variable measurement equation of Corporate Governance $(\eta 1)$

$\xi 3=\lambda 19 \times 19+\varepsilon 11 \quad:$ Focus to board

$\xi 3=\lambda 20 \times 20+\varepsilon 12 \quad: \quad$ Law and regulation

$\xi 3=\lambda 21 \mathrm{X} 21+\varepsilon 13 \quad: \quad$ Effective, efficient, economical, and productive organizational resource

$\xi 3=\lambda 22 \times 22+\varepsilon 14 \quad:$ Transparency, accountable, responsible, independent, and fairness principles

$\xi 3=\lambda 19 \times 19+\varepsilon 15 \quad: \quad$ Organization purpose

$\xi 3=\lambda 20 \times 20+\varepsilon 16 \quad: \quad$ Strategy evaluation

Variable Measurement Equation of Public Organization Performance ( $\eta 2)$
$\eta 1=\lambda 24 \mathrm{X} 24+\delta 17$
: Productivity
$\eta 1=\lambda 25 \times 25+\delta 18$
Customer service orientation
$\eta 1=\lambda 26 \times 26+\delta 19$
: Responsiveness
$\eta 2=\lambda 27 \times 27+\delta 20$
: Accountability

Notation description::
$\xi(k s i)$
: Exogenous latent variable (independent variable)
$\eta($ eta $)$ Endogenous latent variable (dependent variable or independent variable in other equation).
$\gamma($ gamma $):$ Direct correlation exogeneous variable to endogeneous variable
$\beta$ (beta) : Direct correlation between endogeneous variable to endogeneous variable.
$\lambda($ lambda $) \quad: \quad$ Direct correlation between exogeneous latent variable or endogeneous latent variable to its indicators.
$\mathrm{X} 1-\mathrm{X} 8 \quad: \quad$ Exogeneous variable indicators of clarity of budgetary target.
$\mathrm{X} 9-\mathrm{X} 13 \quad$ : Exogeneous variable indicators of decentralization.
$\mathrm{X} 14-\mathrm{X} 18 \quad$ : Exogeneousvaraible indicator of performance measurement system.
$\mathrm{X} 19-\mathrm{X} 21 \quad$ : Endogeneous indicator of quantity performance 
X22 - X26 : Endogeneous variable indicator of quality performance

$\varphi($ phi $) \quad:$ covariance/correlation between exogeneous variable

E(epsilon) : Measurement error from exogeneousvaraible indicator

$\delta($ delta $) \quad: \quad$ Measurement error from endogeneous variable indicator

$\zeta(z$ eta $) \quad:$ Error in equation between exogeneousvariable and/or endogeneous variable to endogeneous variable.

\section{Result And Discussion}

The result of Hypothesis I Test: Asymmetric information influences transaction cost.

Hypothesis I will be tested by seeing the paradigm reflecting its hypothesis which is the influence of asymmetric information ( $\mathrm{x}$ ) to transaction cost $(\mathrm{h} 1)$. The result of Hypothesis I test is presented in figure 2. The significance of asymmetric information influence to transaction cost is $(0,919 \times 0,919 \times 100 \%)=84.5 \%$. in addition the Influence of asymmetry information to transaction cost shows t value (value of 11.25).

\section{Figure2. Path Diagram Structural Equation Modeling (SEM) or The effect of asymmetric information to} Transaction Cost

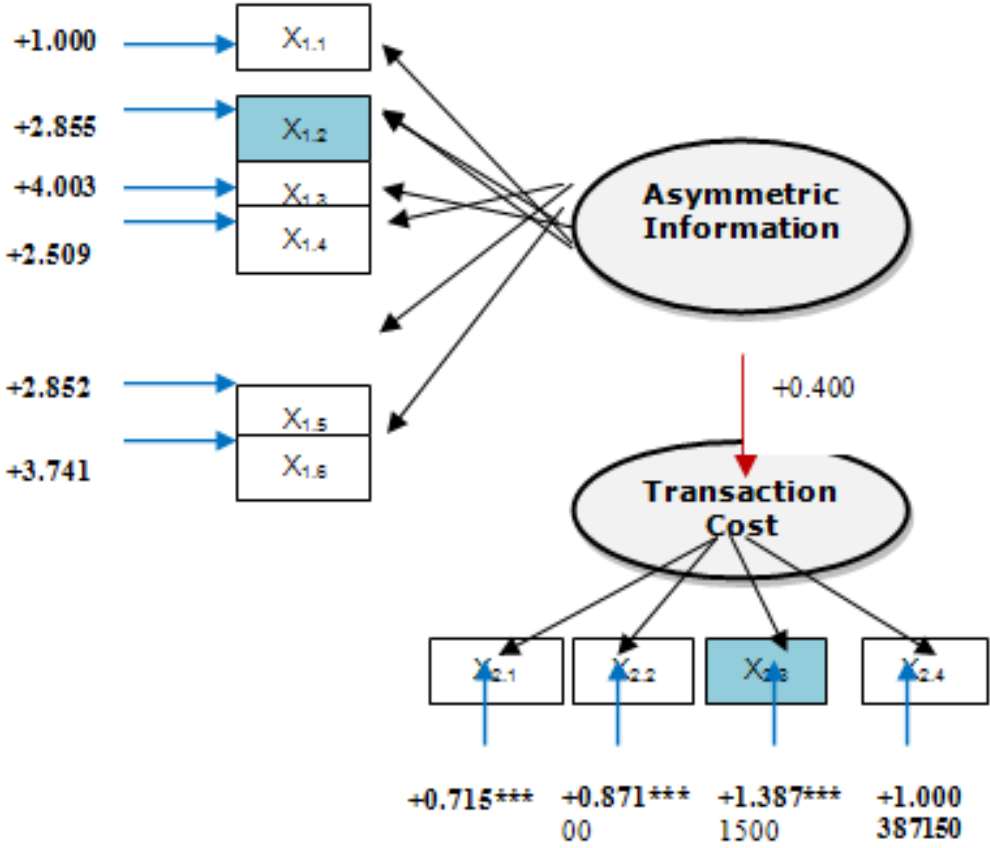

Source: Treated Research Data, 2013

In this asymmetric information variable has positive influence to the transaction cost. This result is based on respondent's answers which has high answer in the indicator of information had by subordinate compared with their superior by having highest average of $73 \%$ which is included in first high criteria of asymmetry information dimension. By having high asymmetry information, there will be a tendency to trigger the emergence of transaction cost resulted from interaction of interrelation between actors from the cause of opportunistic principal-agent relationship..

It means that the higher asymmetry information in an institution the higher the transaction cost. This could happen because of the information used to make policy is not information which reflects the real situation. Principal will get bias information from agent, so that there will be tendency for agent to achieve institution purpose easily.

Thus, the effect of asymmetry information to transaction cost has significance of $84.5 \% /$ This means that asymmetry information, measured for its uncertainty, will influence transaction cost about $84.5 \%$. Therefore in asymmetry information, it should be noticed more about actors bounded rational characteristic which is full of opportunistic behavior. Only $15.5 \%$ of transaction cost is influenced by other variable.

\section{The Result of Hypotheis II Test: Transaction Cost Influences Corporate Governance}

Hypothesis II will be tested using paradigm which refelcts the hypothesisof transaction cost influence (X3) to Corporate Govenrnance (Y1). The result of Hypothesis I test is presented in figure 3. The level of the 
effect of asymmetry information on transaction cost is $0,919 \times 0,919 \times 100 \%)=84.5 \%$. The influences of asymmetry information on transaction cost have $\mathrm{t}$ value of 11.25 . Therefore, the influence of asymmetry information on transaction cost has significance of $84.5 \%$. It means that asymmetry information measured by its uncertain characteristics will influence transaction cost by $84.5 \%$. Therefore, in asymmetry information the researcher should notice more on bounded rationality of actors which is full of opportunistic behavior. Only $15.5 \%$ transaction cost making is influenced by other factors.

In this research, transaction cost variable could be measured by four dimensions, which are actors, transaction attribute, governance structure, and institution environment, which all of them are significantly influential with these indicators. The most dominant influential indicator is governance structure $\left(\mathrm{X}_{2.3}\right)$. Transaction cost variable has positive influence to corporate governance because the most loading factor in transaction cost variable is governance structure with positive value of $+1,387$. Thus, it is natural if this factor influences the level of corporate governance. It could be explained that the higher the transaction cost, the worse the corporate governance in the institution. It happens because of insufficient understanding from company's owner about business and company knowledge, all regulations about the owner's and manager's authority in order to make quick decision, and improvement of internal control system.

\section{Figure 3: Path Diagram of Structural Equation Modeling (SEM) or Effect of Transaction Cost to Corporate Governance}

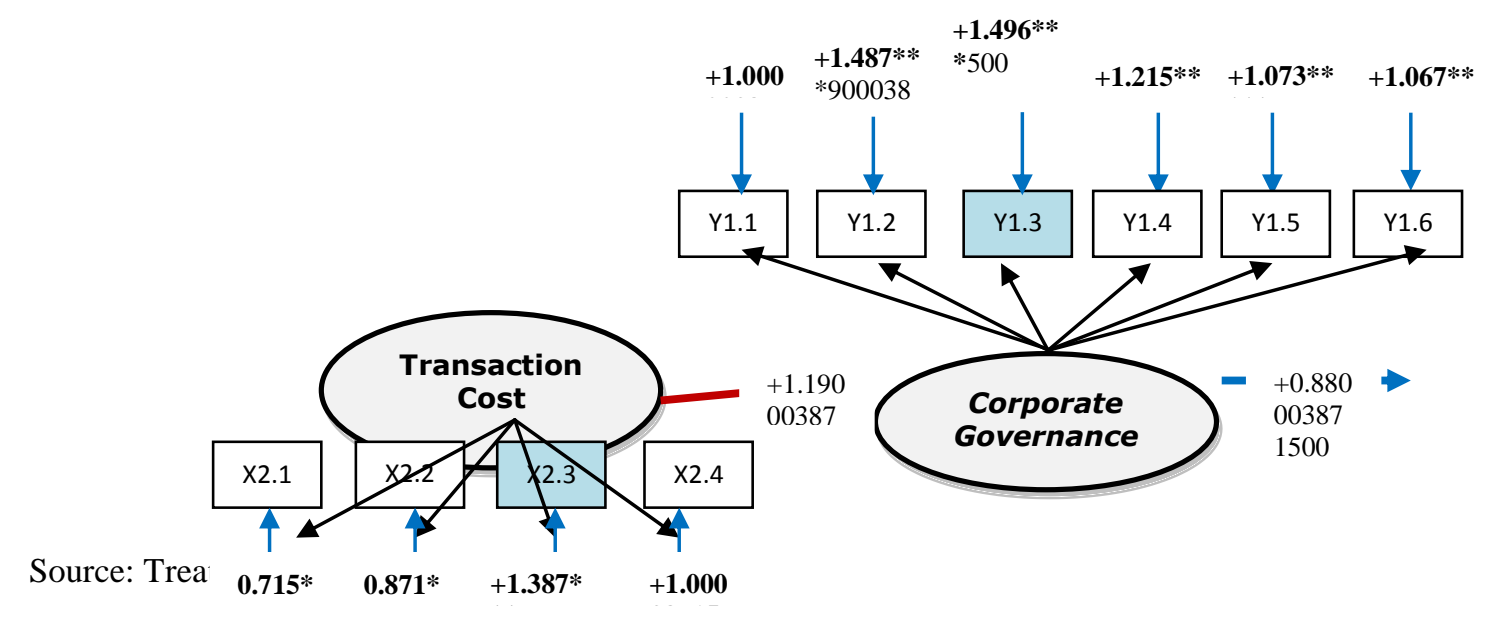

The emergence of economic transaction cost, according to Williamson (1990) is because of market failure as the consequence of opportunistic behavior and limited rationality of transacting parties. In economic transaction cost assumes that companies tend to search for the cheapest transaction cost, such as comparing transaction cost between market transaction with transaction cost in the company itself (hierarchial transaction) or as known as a term "make or buy"

In accordance with Milgron and Roberts's (1992) statement stating that transaction cost includes all loss which emerge from decision makings, plans, regulations, or inefficient agreement, and imperfect enforcement of agreement. In summary, transaction cost covers all costs that affect performance from various natural resource organization and production activity.

\section{Hypothesis III Test Result: Effect of Asymmetric Information to Corporate Governance}

Hypothesis III will be tested in compliance of asymmetry information (X1) with Corporate Governance (Y1). Based on response distribution, it could be inferred that asymmetry information gets high score of $73 \%$ on $\mathrm{X}_{1.1}$ indicator and transaction cost gets high average score of $69 \%$ on $\mathrm{X}_{2.2}$ indicator. Further analysis based on factor loading stated that information indicator which possessed by subordinate compared to its superior was dominant in correlation with governance structure, which has factor loading of 0.784 .

Based on the anlysis result above, it is proved that asymmetry information has signifficant effect to corporate governance. Positive marked coefficient indicates that the higher asymmetry information the higher transaction cost resulting lower corporate governance. On the contrary, the lower transaction cost will result in the higher corporate governance. 
Figure 4. Path Diagram Structural Equation Modeling (SEM) orEffect of Asymmetric Information to Corporate Governance

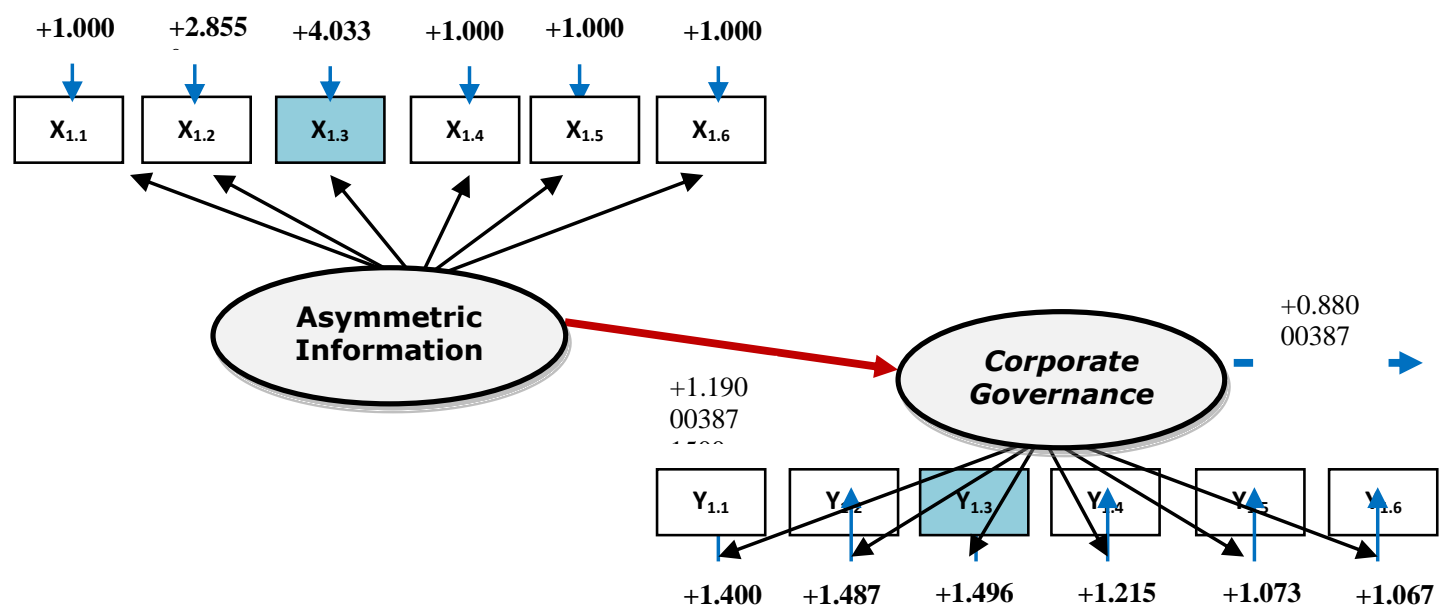

Source: Treated Research Data, 2013

The result of this research supports the statement of Pratt and Zechauser (1985) that asymmetric information could influence the market efficiency, in which one of the parties tries to minimize information gap by making some efforts to expense some amount of transaction cost which has to be guaranteed by parties who transact in condition such as fake information situation, actors who behave opportunistically, and actors with limited rationality. Transaction cost approach acknowledges that many business trades characterized as imperfect or asymmetric in which the underlining concepts of transaction cost are limited rationality, opportunistic behavior, specified asset, and asymmetric information. (Hobbs,1997).

Statement from Williamson (1995) also stated that incomplete and uncertain information refers to situation where all transacting parties are facing the same level of information yet still it is the incomplete one. Dorglas (1995) analyzed one of the aspects of human behavior that was opportunistic behavior in which(1) Basically, organization had particular level of conflict for achieving organization goal, because of the information discrepancy between owner and manager who had complete information of what they do is in correspond with efficiency and effectiveness. (2) Information was an important commodity since more reliable information could ensure security of what agent is doing. Human behavior had personal interest which submit to rational boundary and tend to opt the slightest risk. Therefore, there were possibilities that agent did not act for the optimization of principal interest (Jensen and Meckling, 1967) and principal would find difficulties to ensure agent to act to maximize principal's prosperity. (Budiono, 2005 in Pudyastuti, 2009)

\section{Result of Hypothesis IV Test: Effect of Asymmetry Information to Public Organization Performance through Corporate Governance}

The fourth hypothesis test in accordance with the paradigm of this research was done to test the effect of asymmetry information (X1) toward Public Organization Performance (Y2) through Corporate Governance (Y1). Figure 5 shows diagram of structural equation modeling as a result of calculation using a program AMOS. the significance of the effect of asymmetry information to public organization performance through corporate governance is $\{(0,919 \times 0,919) \times(0,746 \times 0,746)\} \times 100 \%=47,1 \%$. It means that, through strategic planning, external business environment gives positive and significant impact.

In other hand the direct effect of asymmetry information to public organization performance through Corporate Governance results the occurrence of performance degradation of the company in the amount of $0.372 \%$. It means that corporate governance, , in this case as intervening variable, gives positive impact to asymmetry information resulting in degradation of public organization performance. However, there is $52.9 \%$ influence from other variables to public organization performance beside asymmetry information and corporate governance. 
Figure 5 Path Diagram of Structural Equation Modeling (SEM) or

The Effect of Asymmetry Information to Public Organization Perfomance

Through Corporate Governance

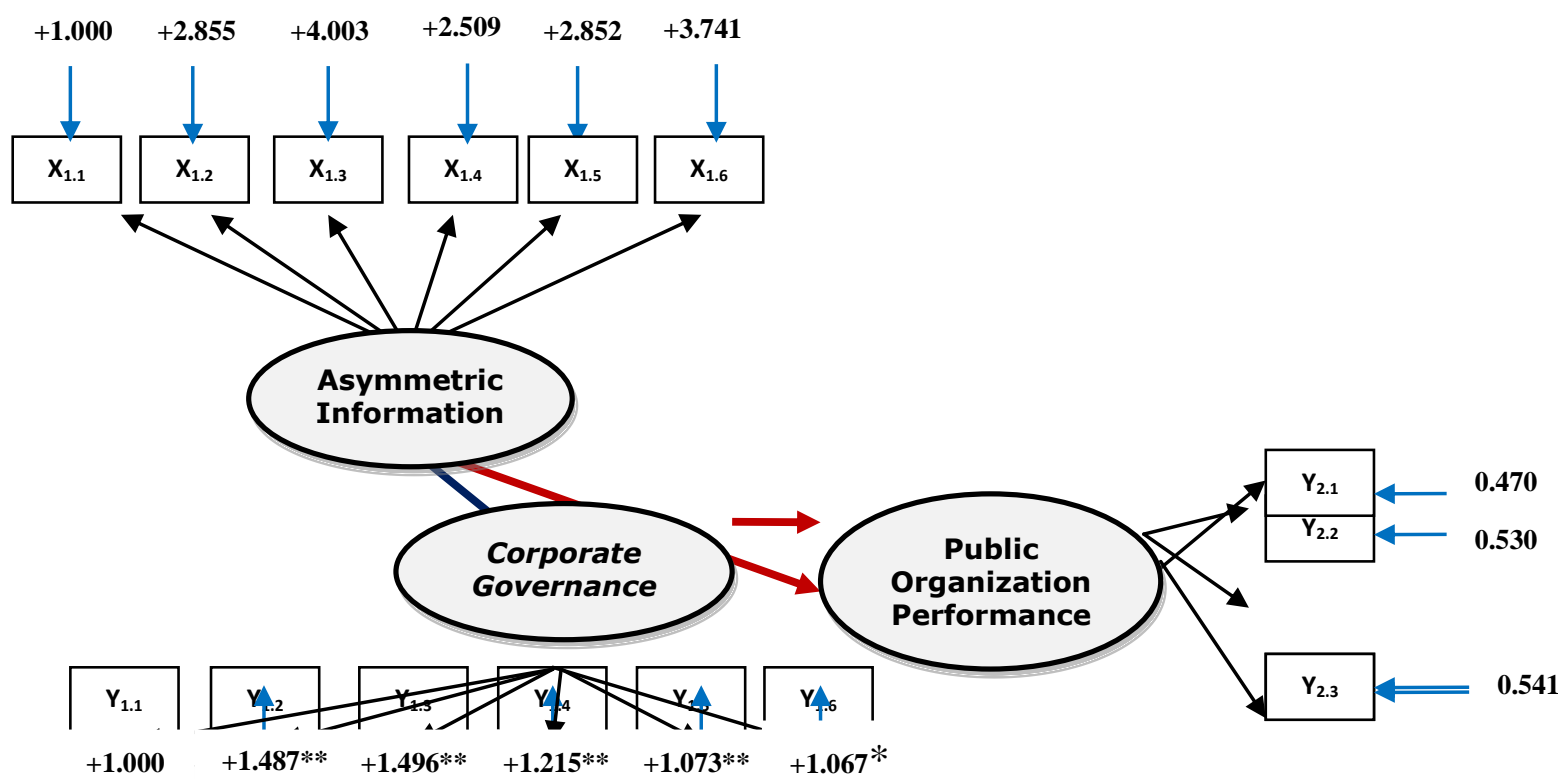

Hypothesis V Test Results: Transaction Cost to Public Organization Performance Through Corporate Governance

The fifth hypothesis tested is the influence of Transaction Cost (X2) to Public Organization Performance (Y2) through Corporate Governance (Y1). Based on respondent distribution responses, it could be answered that transaction cost get high average scores of $73 \%$ in indicator X1.1 which is considered as high criteria and transaction cost get high average scores of $69 \%$ for indicator X2.2 affecting public organization performance level.

Figure 6. Path Diagram structural Equation Modeling (SEM) or

The Effect of Asvmmetric Information to Public Organization Performance through Corporate $+1.387^{*} \quad$ Governance $* * 1500$

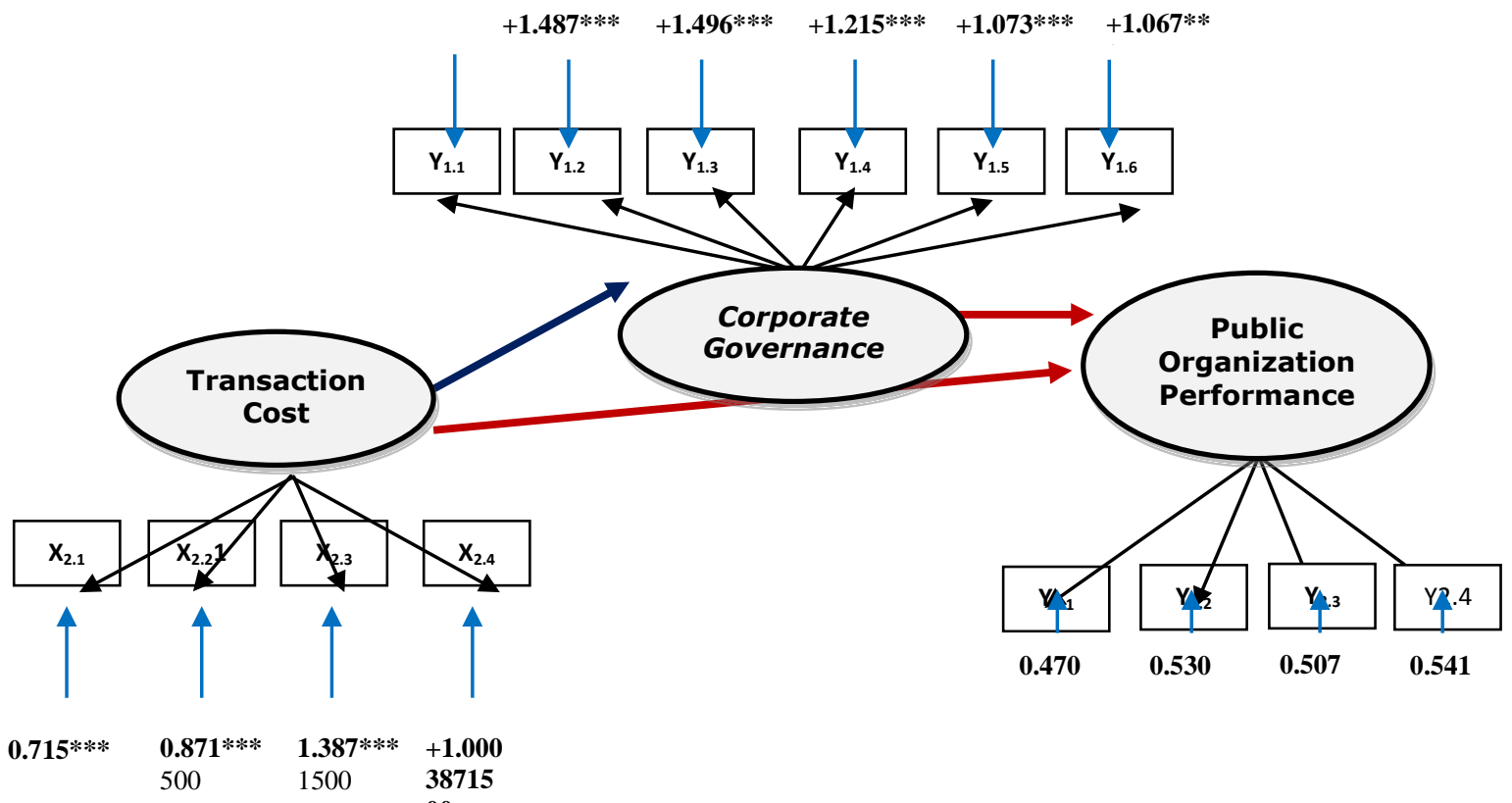


Source: Treated Research Data, 2013 (Appendix 4)

The most factor which influences asymmetric information variable are potential performance (X3) and activity achievement. Both indicators have signifficant effect to asymmetry information variable because inside these indicator contain two important elements, those are: discipline and officer's earnessness in providing service and service information openness in PDAM of Malang Regency. Both indiators obviously affecting asymmetry information varible because when PDAM officer did not earnestly providing service, the selfishness will occur, and it had tendecy to opportunistic behavior. If those traits happen, It would be normal when information became more asymmetry.

The earnestness in providing service encourages a statement that this information disproportion is called asymmetry information with an assumption that each individual act to maximize their own interest resulting agent abuses asymmetric information they know to conceal some unknown information by the principal. Asymmetric information and conflict of interests happening between principal and agent stimulate agent to provide fake information to the principal, especially if the information is related to performance evaluation of the agent. (Scott, 2003).

Transaction cost variable aspect shows that those four indicators used in measurement are all signifficant and the govenrance structure is the most dominant variable. That indicator is able to influence transaction cost variable since it contains service flow simplicity and other services which are not complicated and have clear informations. Based on that fact, it means that if the service flow of PDAM Malang Region could be simplified, it can be ensured that the transaction cost is reducable.

If we associate the asymmetric information and its impact to transaction cost based on available indicator, the correlation will be drawn like this: if PDAM officer earnestly working with discipline, certaintly it will reduce opportunistic behavior in every officer which leads to officers who will provide optimum service and information. By having optimum service, information obtainded by customers could be clearer and service flow become less complicated which lead to reduced transaction cost.

According to those consideration, transaction cost in management of PDAM Malang Region which is also dominant affects public organization's performance. This shows that realizing oraganization's performance needs good governance system, such as proper regulation, simplified bureaucracy and regulation which manage the governance system itself and enforced control system, would trigger efficiency inside economic institution of PDAM Malang Region.

The result of this research support a statement from Husnan (2005)that a good control system (including its reinforcement) gives a high chance for agents to make decision which benefit themselves. In other words, mechanism to effectively enforce regulation is needed.

\section{The Result of Hypothesis VI Test : The Effect of Corporate Governance to Public Organization Performance}

According to the test result, it is found that corporate governance influences the public organization performance. The Corporate Governance variable in this research is formed by 6 dimensions, they are: focus on the board, law and regulation, effectiveness, efficiency, economical and productivity of resources, organization aim, and internal control. Since those six dimensions in corporate governance has positive loading factor, it means that they could give influence to public organization's performance. . The result of correlation analysis proves that there is significant influence between corporate governance and public organization performance. Positive coefficient indicates that the higher corporate governance the higher public organization performance. On the contrary, the lower corporate governance will result in the lower public organization performance. By implementing corporate governance, it is expected to discourage manipulation activity by manager, so that performance report reflects the real economic condition of the company. (Jensen, 1993).

Figure 7 Path diagram of Structural Equation Modeling (SEM) or The Effect of Corporate Governance to Public Organization Performance

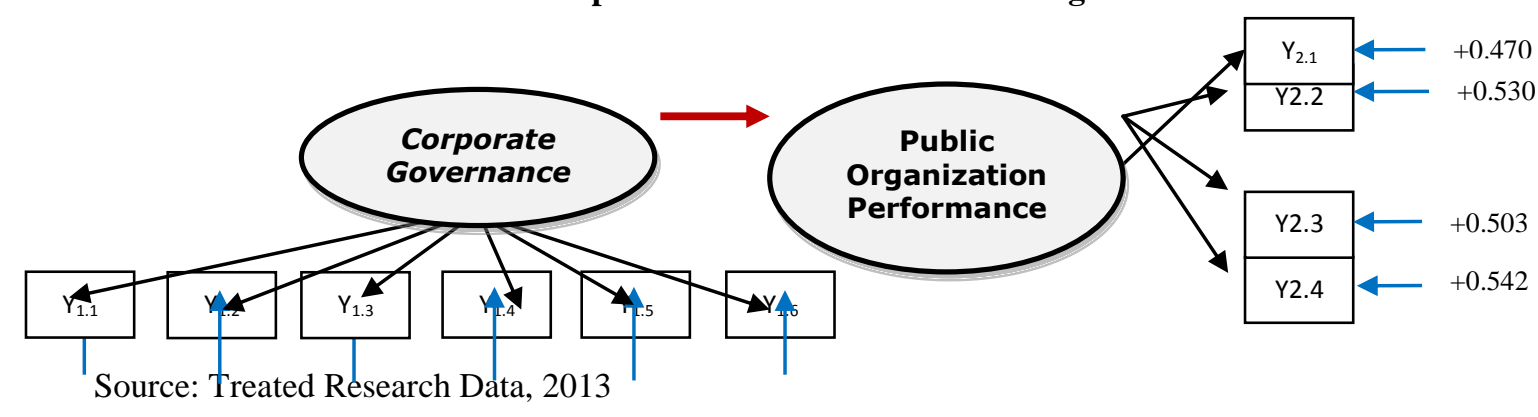


In variable measurement of Corporate Governance in figure 7, it can be known that all indicators has significant effect, which are focus on the board, law and regulation, efficiency, effectiveness, economical, and productivity of organization resource, transparency, accountability, responsibility, independency, and fairness (TARIF), organization aim, and strategic control with the most dominant loading factor of indicators are transparency, accountability, responsibility, independency, and fairness $\left(\mathrm{X}_{22}\right)$.

This research has two hypothesis test segments related to the structural model. Causality correlation which is expanded in this hypothesis model was tested with null hypothesis through t-test, as available in regression analysis, stated that regression coefficient between correlation on both variables is the same with zero. The statistical value of Critical Ratio (CR) will have t distribution degree of 37 . The following statement will describe test result of 6 hypotheses in structural model which is proposed in this research. The usage of gamma symbol shows the significance of effect influence exogenous construct to endogenous construct. While beta symbol shows significance of influence of endogenous construct to endogenous construct. To test the correlation between variable in hypothesis, it will be described using path coefficients which shows correlation between variables.

The test was conducted by comparing probability value (p) and will be significant if the value of $\mathrm{p}<$ 0.005. According to those criteria and by looking at figure 7.1 and 7.2 below, hypothesis test in structural model has correlation with coefficient regression test in every path in coefficient results.

Table 1 The Result of SEM Hypothesis - The Direct Effect

\begin{tabular}{|c|c|c|c|c|c|c|}
\hline Hypothesis & $\begin{array}{c}\text { Independent } \\
\text { Variables }\end{array}$ & $\begin{array}{c}\text { Dependent } \\
\text { Variables }\end{array}$ & $\begin{array}{c}\text { Path } \\
\text { Coefficient }\end{array}$ & $\mathrm{Cr} \geq 2$ & $\begin{array}{c}\text { P-Value } \\
\leq 0.05\end{array}$ & Explanation \\
\hline $\mathrm{H} 2$ & Transaction Cost & $\begin{array}{l}\text { Corporate } \\
\text { Governance }\end{array}$ & 0.949 & 3.953 & 0.000 & Significant*** \\
\hline $\mathrm{H} 3$ & $\begin{array}{l}\text { Asymmetry } \\
\text { Information }\end{array}$ & $\begin{array}{l}\text { Corporate } \\
\text { Governance }\end{array}$ & 0.129 & 0.900 & 0.368 & Not Significant \\
\hline H6 & $\begin{array}{l}\text { Corporate } \\
\text { Governance }\end{array}$ & $\begin{array}{l}\text { Public } \\
\text { Organization } \\
\text { Performance }\end{array}$ & 1.005 & 4.255 & 0.000 & Significant $* * *$ \\
\hline
\end{tabular}

Source: Treated Research Data, 2013 (Appendix 4)

This test shows answers of all proposed hypothesis and accepts applicable hypothesis except hypothesis 3 stated that asymmetric information has positive effect but insignificanct to corporate governance. Meanwhile the correlation between variables which are hypothesized could be seen at figure 6.1. below. The Thick and colored line shows whether the correlation between variables are significant or not.

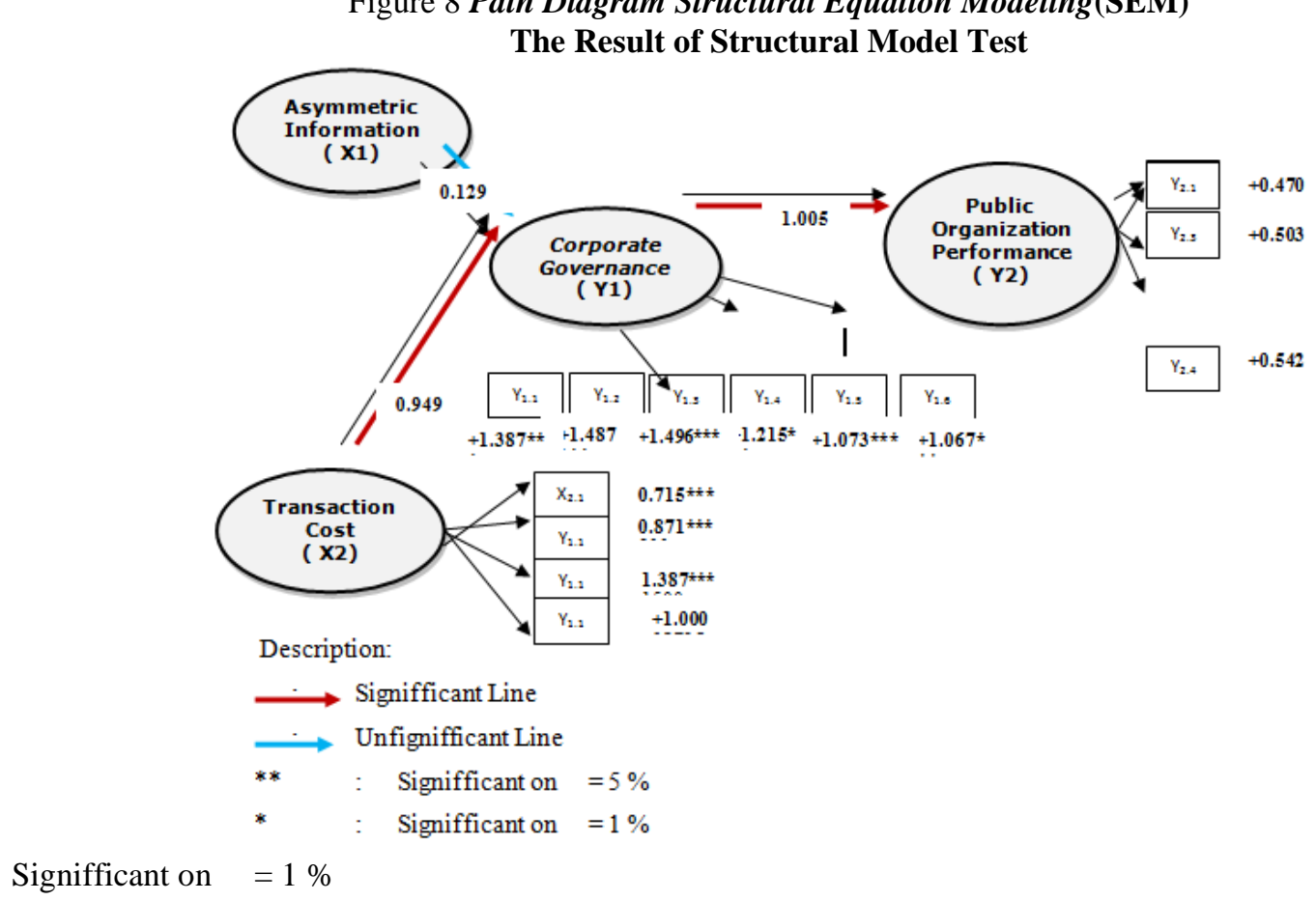




\section{The Direct Effect of Transaction Cost to Corporate Governance}

In result of analysis of hypothesis 2 , there is direct effect of transaction cost (X2) to Corporate Governance (Y1) with coefficient of $0.130(0.129 \times 1.005)$ which both effects are significant (Asymmetric Information $\rightarrow$ corporate governance). Since the coefficient is positive $(0.949)$ with p-value < alpha $(0.05)$, it indicates that both correlations are linear so that it could be concluded that it has direct significant effect between transaction cost (X2) and corporate governance (Y1). It means that the higher transaction cost will result on the worse corporate governance.

Based on the result of correlation analysis, there is significant influence between transaction cost and corporate governance. Positive coeficient indicates that the higher transaction cost will result on the higher corporate governance. On the contrary, less transaction cost will result on less corporate governance.

These results support another research conducted by Gilardi (2001) in which stated that public sector organization these days is facing pressure in order to be more efficient, considering the economical and social cost, and also negative impact on activities. Some matters related to public matters have principal-agent correlation whenever one individual's actions have an effect on another individual or whenever one individual depends on the action of another.

Based on those calculations, emergence of transaction cost in managing PDAM of Malang Regency is dominantly influenced by governance structure dimension. By having good company governance, such as having regulation and deregulation of strong legal framework, bureaucracy competence of quality of public service, decentralization authority of decision making, and organization resource will trigger efficiency in economic institution of PDAM in Malang Regency. As a result, corporate governance is needed to accommodate interests and relationship with management, board of directors, board of commissioners, shareholders, and stakeholders who manage and direct company's activity. (OECD, 2004).

The more complex company's management activity increases the needs of good corporate governance. Professional implementation of corporate governance is fundamental in correlation with market competitiveness and globalization which keep increasing. By taking priority to the improvement and implementation of corporate governance, company could lead to cheaper cost and improve performance which will increase customer's trust and market trust. (Sugiarto, 2006)

\section{The Direct Effect of Asymmetry Information to Corporate Governance}

The result of the Analysis of hypothesis 3 shows direct effect of asymmetry information to corporate governance which has coefficient of 0.129 with p-value of $0.368>$ alpha (0.05), so it could be concluded that there is no significant effect between asymmetric information and corporate governance. It means that the amount of value of asymmetric information will not influence the level of corporate governance.

Based on the result of correlation analysis, there is signifficant influence of asymmetric information to corporate governance. By having positive coeficient, it indicates that the higer asymmetric information the higer asymmetric information which results on the lower corporated governance. On the contrary, the lower asymmetric information will result on the higher corporate governance.

The result of this research supports the statement from PrattandZeckhauser (1985) who stated that asymmetric information could influence market efficiency in which one party tries to lessen information discrepancy by issuing an amount of transaction cost that has to be burdened to parties who trade in condition where the information available is imperfect, many actor behaving opportunistically, and limited rationality of the actors. Transaction cost approach acknowledges that there are many business transactions which are included as imperfect or asymmetric where underlining transaction cost concepts are bounded rationality, opportunistic behavior, asset specification, and asymmetric information (Hobbs, 1997).

To solve those problems, according to corporate governance, devices such as governance (governing body and management appointments) followed by clear definition of roles and powers and code of conducts in a governance mechanisms which is reliable, are needed. Essentially this needs to ensure interest from various parties related to the company.

\section{The Direct Effects of Corporate Governance to Public Organization Performance}

In the result of hypothesis 6 analysis shows direct effect corporate governance to public organization performance which has coefficient of 1.005 with p-value < alpha (0.05). It could be concluded that there is significant effect of corporate governance to public organization performance. Positive coefficient (1.005) indicates that the correlations of both variables are linear. It means that the higher corporate governance, the higher public organization performance.

The result of analysis correlation proves that there is significant influence between corporate governance and public organization performance. By showing positive coefficient it indicates that the better corporate governance the better public organization performance. By implementing corporate governance it is 
expected to reduce tendency of manipulation behavior from the manager so that the performance reports reflect the real economic condition of the corporate. (Jensen, 1993)

1. Based on correlation score between asymmetry information and transaction cost of 0.0701 with $\mathrm{p}$ value $0.13<$ 0.05 it can be concluded that there is positive correlation between asymmetry information and transaction cost. This indicates that the higher asymmetric information will result on highertransaction cost. Correlation score of 0,701 or $70.1 \%$ shows strong correlation between asymmetry information and transaction cost.

Beside direct influences, in SEM anaysis method there are also indirect effects which are resulted from multiplication between two direct influences as shown in table 7.2.

Table 2The Result of SEM Hypothesis Test - The Indirect Effect

\begin{tabular}{|c|c|c|c|c|c|c|}
\hline $\begin{array}{c}\text { Hypot } \\
\text { hesis }\end{array}$ & $\begin{array}{c}\text { Independent } \\
\text { Variable } \\
\end{array}$ & $\begin{array}{c}\text { Intervening } \\
\text { Variable } \\
\end{array}$ & $\begin{array}{c}\text { Dependent } \\
\text { Variable } \\
\end{array}$ & Path Coefficient & $\begin{array}{c}\text { P-Value } \\
\leq 0.05\end{array}$ & Explanation \\
\hline $\mathrm{H} 4$ & $\begin{array}{l}\text { Transaction } \\
\text { Cost }(\mathrm{X} 2)\end{array}$ & $\begin{array}{l}\text { Corporate } \\
\text { Governance (Y1) }\end{array}$ & $\begin{array}{l}\text { Public } \\
\text { Organization } \\
\text { Performance (Y2) }\end{array}$ & $\begin{array}{c}0.954 \\
(0.949 \times 1.005)\end{array}$ & 0.954 & Significant \\
\hline $\mathrm{H} 5$ & $\begin{array}{l}\text { Asymmetric } \\
\text { Information } \\
(\mathrm{X} 1)\end{array}$ & $\begin{array}{l}\text { Corporate } \\
\text { Governance (Y1) }\end{array}$ & $\begin{array}{l}\text { Public } \\
\text { Organization } \\
\text { Performance (Y2) }\end{array}$ & $\begin{array}{c}0,130 \\
(0.129 \times 1.005)\end{array}$ & 0.129 & Not Significant \\
\hline
\end{tabular}

Source: Treated Research Data, 2012 (Appendix 4)

\section{The Indirect Effect of Asymmetric Information to Public Organization Performance Through Corporate Governance as Mediator}

In the analysis of indirect effect of asymmetric information (x1) to public organization performance (Y2) through Corporate Governance as mediator shows coefficient of $0.130(0.129 x 1.005)$ which one of the direct influences is not significant (Asymmetric information $\rightarrow$ corporate governance not significant and corporate governance $\rightarrow$ public organization performance significant). Therefore it could be concluded that there is no significant indirect influence between asymmetric information (X1) and public organization performance (Y2) although corporate governance variable (Y1) has changed.

This understanding means that in principal agent correlation it has no direct effect to corporate governance, considering the correlation is associative and more identical to compromistic behavior where actors who input the information has limited rationality by doing opportunism. Principal is emphasizing more on self of interest which happens in an institution by making regulation which the regulation itself is cost incurred in institution so that indirect asymmetric information directly influence corporate governance, but mediated by transaction cost. This correspondence with statement stated by Williamson (1990) and North (1987) that defines transaction cost as cost to run economic system.

\section{Conclusion}

Based on analysis result of discussion and research purpose, we could conclude about the influence of each variable as follows:

1. Asymmetric information has significant effect to transaction cost. It indicates that when the value of asymmetric information arises, it will increase transaction cost. It means that the higher asymmetric information the higher transaction cost. This result supports a research conducted by Rahmawati et.al (2006) in which stated that information has positive influence to transaction cost.

2. Transaction cost has significant effect to corporate governance. It indicates that both correlations are linear. It means that the higher transaction cost, the higher corporate governance. This result supports a research conducted by Syakhroza (2005) in which stated that transaction cost has positive correlation to corporate governance.

3. Asymmetric information has significant effect to corporate governance. It indicates that the higher asymmetric information the worse corporate governance and in the contrary, the less asymmetric information the better corporate governance. This research supports a statement from Pratt and Zeckhauser (1985) that asymmetric information could affect market efficiency, where one of the parties always tries to lessen the discrepancy by spending an amount of transaction cost which has to be certified by all parties.

4. Transaction cost has insignificant influence to public organization performance, through corporate governance as a mediator. By having positive indirect effect, it means that the higher transaction cost the higher public organization performance if the value of corporate governance is also getting higher. This results supports a research conducted by Yeager (1999) in Yustika (2006) stated that correlation between transaction cost and institution has strategic meaning as indicator of efficiency level which means institutional efficiency indicator is observed from the level of transaction cost which occur from economic transaction and the less transaction cost shows an efficient institution.

5. Asymmetric information has indirect significant effect to public organization performance through corporate governance as a mediator. It means that the amount of asymmetric information has no effect on 
the level of public organization performance even though the amount of corporate governance has change. This result supports a research conducted by Jensen (1993) stated that how major the increasing or decreasing of the amount of asymmetric information, it will have no effect to the level of corporate governance.

6. Corporate governance has significant effect to public organization performance. since the coefficients is positive (1.005) it indicates that correlation between both variables is linear. The higher corporate governance, the higher public organization performance. By having positive influence between corporate governance variable and public organization performance means that the higher working intensity of public organization. The result of this research supports a research conducted by Rue and Byars, 1981 in Keban 1995, Syakhoroza, 2005, stated that the increase or decrease of corporate governance will affect the increase or decrease of public organization performance.

\section{Bibliography}

[1]. Anthony, Robert N. and Vijay Govindarajan, 2001.Management Control Systems.Boston : McGraw-Hill Co. Vol.68:400-401,281.

[2]. Alwi, Syafaruddin (2002). ParadigmaBaruPeningkatanKinerjaBadan Usaha Milik Daerah (BUMD), JurnalSiasatBisnis, Vol. 1 Hal. 81-91

[3]. Beckman.Volker. 2000."A Theory of Determination of the Mark-up Under Oligopoly," Journal of Economic Literature. Vol. 38, pp. 595-613.

[4]. Belkaoui, Ahmed Riahi. 2001. Accounting theory, $4^{\text {th }}$ Edition, Thomson Learning.

[5]. Benham, Alexandra and Lee Benham. 2000. "Measuring the Costs of Exchange", in Institutions, Contracts and Organizations: Perspectives from New Institutional Economics, Ménard (ed.), Edward Elgar Press, 367-375

[6]. Coase, Ronald.H. 1937, The Nature of the firm. Economica, New Series, IV: 386-405. Reprinted in: The Firm, the market, and the law, the University of Chicago Press, Chicago, 1988.

[7]. $\quad$----------- 1998. "The New Institutional Economics," The American Economic Review, Vol. 88(2), pages 72-74, Paper and Procedding of the Hundred and Tenth Annual Meeting of the American Economics Associating.

[8]. Gana, Frans. \& Moenardy, Khalid 2008. Kajian Pendirian Perusahaan Daerah, Jurnal Bisnis Usahawan Vol. 6 Nomor 2

[9]. Gilardi, Fabrizio. 2001. Principal-agent models go to Europe: Independent regulatory agencies as ultimate step of delegation. Paper presented at the ECPR General Conference, Canterbury (UK), 6-8 September 2001.

[10]. Husnan, Suad 2005.Penjualan Saham BUMN; ApakahTerjadiDistribusiKemakmuran

[11]. Hobbs,J.E. 1997. Measuring the Importance of Transaction Costs in Cattle Marketing.American Journal of Agricultural Economics. Vol. 79 (4): $1083-1095$.

[12]. Jensen, M.C; and Meckling,W.H. 1976. Theory of the firm : Managerial behavior, agency costs, and ownership structure. Journal of Financial Economics, 11 (4): 5-50.

[13]. Lupia, Arthur \& Mathew McCubbins. 2000. Representation or abdication? How citizens use institutions to help delegation succeed. European Journal of Political Research, 37: 291-307.

[14]. Milgrom, P. and J. Roberts. 1992., Economics, Organization and Manajement Hill, Engleweed Cliffs, New Jersey.

[15]. Nicholson, Walter. 1995. Microeconomics theory: basic principles and extensions. 5th ed. Fort Worth: The Dryden Press.hal.430432

[16]. Noor, Henry Faizal. 2003. WacanaOtonomi Daerah: ProspekdanTantangan BUMD sebagaiPenggerakEkonomi Daerah, Jakarta, Jurnal Forum Inovasi, FISIP-IU Np.7, Juli-Agustus 2003, hal.57

[17]. North, Douglas C. 1997. Institutions, Transaction cost and Economic Growth Economic Inquiry. Vol. 25

[18]. Pratt andZeckhauser.1985.Principals and Agents. Economy Foundationpf Strategy

[19]. Pass. Tiiu.2000 Gravity Approuch for Modelling Trade Flows Between Estonia and The main Traiding Partners University of Tartu

[20]. Pudyastuti. 2009. "Analisis Hubungan Mekanisme Corporate Governance, Ukuran Perusahaan dan Leverage Terhadap Manajemen Laba pada Perusahaan Manufaktur yang Terdaftar di BEI". Universitas Diponegoro Semarang.

[21]. Rahmawati, dkk. 2006. Pengaruh Asimetrik Informasi terhadap Praktek Manajemen Laba pada Perusahaan Publik yang terdaftar di Bursa Efek Jakarta, (online) tersedia htpp://muahaeriefendi files wordpres.com/2007/12/k-akpm09-sna9 padang. pdf 6 Maret 2008

[22]. Sunarsip 2009. Kepala Ekonom The Indonesia Economic Intelligence (IEI), Mantan Tenaga Ahli Menteri Negara BUMN RI. Dapat dihubungi di sunarsip@gmail.com. dimuat Jawa Pos Group, Jum'at, 13 Maret 2009

[23]. Scott, William R. 2003. Financial Accounting Theory.Second Edition. Canada : Prentice Hall.

[24]. Sifia, Ivy dan Aswanto, Tri. 2010. Reiventing Goverment : Audito Inspektorat IV Itjen DKP diakses tanggal 5 Oktober 2011 halaman 1

[25]. Stigler.J.,George. 1961. The Economics of Information. The Journal of Political Economy, Vol.69. Issue 3.213-225

[26]. Sugiarto.2006. "Good Corporate Governance MampukahMeningkatkanKinerja. Perusahaan?" .JurnalAkuntabilitas, Vol 6, No 1. September :hal $34-46$

[27]. Syakhoroza, Ahkmad.2005. Corporate Governance : SejarahdanPerkembangan, Teori, Model danSistem Governance sertaAplikasinyapada Perusahaan BUMN., PidatoPengukuhan Guru Besar, Universitas Indonesia, Jakarta

[28]. OECD 2004.Principles of Corporate Governance (www.oecd.org)

[29]. Ujiyantho, Arif. 2007, Mekanismecorporate governance, manajemenlaba dank inerjakeuangan, makalahSimposiumNasionalAkuntansi.

[30]. Williamson, Oliver, 1985.The Economic Institutions of Capitalism. New York: The Free Press. [Reviewed by Alchian\& Woodward, JEL 1988, see above] Free Press, 1985

[31]. 1990.Transaction Cost Economics, The Governance of Contractual Relation. Industrial Organization: Ann Elgar Critical Writing Reader, Chelthenham, UK. . 1995., Organization Theory : From Chester Barnard to the Present and Beyond New York, hal 172-256

[33]. Yustika, Ahmad Erani (2006) EkonomiKelembagaan; Definisi, TeoridanStrategi.PenerbitBayumedia Publishing Malang, hal 100 Yustika,
dan 223

[34]. Zhang, Wuchang. 2000. Economic Organization and Transaction Costs, (1st ed.) Beijing : The commercial Press 